\title{
Hydroxyproline-containing collagen peptide derived from the skin of the Alaska pollack inhibits HIV-1 infection
}

\author{
IN SEUNG JANG and SUN JOO PARK \\ Department of Chemistry, Pukyong National University, Busan 608-737, Republic of Korea
}

Received October 23, 2015; Accepted October 13, 2016

DOI: $10.3892 / \mathrm{mmr} .2016 .5949$

\begin{abstract}
The human immunodeficiency virus (HIV) is a lentivirus that results in acquired immunodeficiency syndrome (AIDS). HIV treatment involving chemical therapeutic agents has improved the quality of life of HIV/AIDS patients. The present study demonstrates that a hydroxyproline-containing marine collagen peptide (APHCP) derived from Alaska pollack inhibits HIV-1 infection in the MT-4 human T cell-line. APHCP inhibited HIV-1 ${ }_{\text {IIIB }}$-induced cell lysis, syncytia formation, reverse transcriptase activity and viral p24 production at non-cytotoxic concentrations; however, APHCP did not inhibit HIV-2 $2_{\text {ROD }}$ infection in MT-4 cells. This suggests that the anti-HIV activity of APHCP is specific to HIV-1. In addition, substitution of hydroxyproline residues in APHCP with prolines impaired its anti-HIV-1 activity, suggesting that the hydroxyl group of hydroxyprolines is required for the anti-HIV-1 activity of APHCP. These results suggested that the marine peptide APHCP may be a novel drug candidate in the development of next-generation therapeutic agents for the treatment of HIV/AIDS.
\end{abstract}

\section{Introduction}

The human immunodeficiency virus (HIV) is a lentivirus that results in acquired immune deficiency syndrome (AIDS). HIV infects critical cells of the human immune system, including $\mathrm{T}$ cells (specifically $\mathrm{CD} 4^{+} \mathrm{T}$ cells), macrophages and dendritic cells, and reduces the numbers of $\mathrm{CD}^{+} \mathrm{T}$ cells. Once the numbers of $\mathrm{CD}^{+} \mathrm{T}$ cells fall below a certain threshold, cell-mediated immunity is lost, increasing susceptibility to life-threatening opportunistic infections. Without treatment, the average survival time of patients following HIV infection is estimated to be 9-11 years. The first case of AIDS was observed in 1981 in the USA. Two years later, Luc Montagnier and his group

Correspondence to: Professor Sun Joo Park, Department of Chemistry, Pukyong National University, 599-1 Daeyeon 3-Dong, Nam-Gu, Busan 608-737, Republic of Korea

E-mail: parksj@pknu.ac.kr

Key words: human immunodeficiency virus, marine, acquired immunodeficiency syndrome, peptide, activity at Institute Pasteur and the group of Robert Gallo at the National Institutes of Health independently discovered the AIDS-causing virus $(1,2)$. This virus was identified and named as HIV (-1) in 1986 (3). In the same year, Montagnier's group discovered a novel type of HIV in West Africa and named it HIV-2 (4). HIV-2 takes longer to cause AIDS and has a low prevalence rate. Following the first discovery, the number of AIDS cases has steadily increased with 35 million people infected worldwide by 2013. In 2013, 2.1 million people were newly-infected with HIV and 1.5 million patients lost their lives to AIDS (5).

With the increase in the incidence of AIDS, numerous research groups have attempted to discover and develop novel therapeutic agents for its treatment. Since the approval of zidovudine (trade name, azidothymidine) as an HIV drug by the USA government in 1987, numerous novel therapeutic agents have been developed. However, the use of these medicines has been terminated due to adverse effects, including a lack of oral availability, cardiac disturbances and drug-resistance. Currently, to minimize resistance and delay the progression of HIV infection to AIDS, multiple drugs acting on different viral targets are typically used in combination. However, anti-retroviral therapy has its caveats and access to such treatment remains a concern around the world, particularly in developing countries. In the developing world, treatment for opportunistic infections is not readily available and thus, low-cost treatments are a necessity.

As a result of this, natural bioactive compounds have been investigated as sources of next-generation anti-HIV therapeutics, which should have greater effectiveness, fewer adverse effects and reduced costs. Marine life may become one of the leading sources of anti-HIV natural products. Marine organisms produce numerous novel substances due to the unique, demanding and aggressive environment in which they exist. Recently, a there has been a focus on developing marine-derived anti-HIV agents. Various studies have reported that marine peptides may be used as anti-HIV agents in functional foods or neutraceuticals and pharmaceuticals, due to their therapeutic potential for the treatment or prevention of infectious diseases (6-10).

The present study revealed that an Alaska pollack hydroxyproline-containing collagen peptide (APHCP) inhibited HIV-1 infection in an MT-4 human T cell line.

\section{Materials and methods}

Materials. Alaska pollack skins were obtained from a local fisheries company and stored at $-20^{\circ} \mathrm{C}$. Alaska pollack skin 
gelatin was extracted in our laboratory. Alaska pollack skins were first washed in ice water containing $0.3 \mathrm{M} \mathrm{Ca}(\mathrm{OH})_{2}$ to remove flesh and other impurities and then washed again with water, neutralized with $0.15 \mathrm{M}$ acetic acid. Gelatin was extracted with distilled water at $45^{\circ} \mathrm{C}$ for $4 \mathrm{~h}$ at the skin/water ratio of 1:5 (w/v). The extract was filtered through two layers of cheese clothes and evaporated at $70^{\circ} \mathrm{C}$ to remove $\sim 70 \%$ of water. The filtrate was dried in a $50^{\circ} \mathrm{C}$ hot-air oven for $12 \mathrm{~h}$. The resulting Alaska pollack gelatin was stored in desiccators for further use. APHCP peptide was prepared as described by Kim et al (11). Briefly, Alaska pollack skin gelatin (1\% w/v) was hydrolyzed with Pronase E (enzyme to substrate ratio, 1:50) at $\mathrm{pH} 8.0$ and $50^{\circ} \mathrm{C}$ for $12 \mathrm{~h}$. APHCP peptide was purified by consecutive chromatographic methods including gel filtration on a Sephadex G-25 column, ion-exchange chromatography on a SP-Sephadex C-25 column, and high-performance liquid chromatography on an octadecyl-silica column. The molecular mass and amino acid sequences of the purified peptides were determined using quadrupole time-of-flight (Q-TOF) mass spectroscopy and N-terminal Edman sequencing analysis, respectively. APHCP is composed of 10 amino acid residues containing a Gly residue at the $\mathrm{C}$-terminus and the repeating motif Gly-Pro-Hyp (787 Da). MTT was purchased from Sigma-Aldrich; Merck Millipore (Darmstadt, Germany). Dimethyl sulfoxide (DMSO) was obtained from Amresco, LLC (Solon, OH, USA). Specific antibodies against p24 and $\beta$-actin for western blot analysis were purchased from R\&D Systems, Inc. (Minneapolis, MN, USA) and Merck Millipore (Darmstadt, Germany).

Cells and viruses. MT-4, H9/HIV- $1_{\text {IIIB }}$ and H9/HIV-2 $2_{\text {ROD }}$ cell lines were obtained from the National Institutes of Health AIDS Reagent Program (Germantown, MD, USA). All cell lines were cultured in RPMI-1640 (Thermo Fisher Scientific, Inc., Waltham, MA, USA) supplemented with $10 \%$ heat-inactivated fetal bovine serum (FBS; Thermo Fisher Scientific, Inc.), $50 \mu \mathrm{g} / \mathrm{ml}$ streptomycin and $50 \mathrm{U} / \mathrm{ml}$ penicillin in $5 \% \mathrm{CO}_{2}$ at $37^{\circ} \mathrm{C}$. Cells were passaged every 2-4 days and maintained at a cell density of $5 \times 10^{5}-1 \times 10^{6}$ cells $/ \mathrm{ml}$. HIV-1 $1_{\text {IIIB }}$ and HIV-2 $2_{\text {ROD }}$ viral particles were obtained from the supernatants of $\mathrm{H} 9 / \mathrm{HIV}-1_{\text {IIIB }}$ and $\mathrm{H} 9 / \mathrm{HIV}-2_{\mathrm{ROD}}$ cell lines, respectively. The viruses were stored at $-80^{\circ} \mathrm{C}$ until use. Viral titer was determined by measuring p 24 production on infection in MT- 4 cells, and expressed as 50\% tissue culture infective dose $\left(\mathrm{TCID}_{50}\right)$.

Cell viability assay. The $50 \%$ cytotoxic concentration of APHCP was determined by MTT assay. MT-4 cells were seeded in a 96-well plate at $2 \times 10^{4}$ cells/well in RPMI-1640 medium containing $10 \% \mathrm{FBS}$. A total of $24 \mathrm{~h}$ later, cells were treated with $0-0.75 \mathrm{mg} / \mathrm{ml} \mathrm{APHCP}$ and incubated for $24 \mathrm{~h}$ at $37^{\circ} \mathrm{C}$. Fresh RPMI-1640 medium containing $10 \%$ FBS was added to each well $24 \mathrm{~h}$ later. After 84 h, $20 \mu \mathrm{l}$ MTT solution (final concentration, $0.5 \mathrm{mg} / \mathrm{ml}$ ) was added to each well and the plate was incubated for $4 \mathrm{~h}$ at $37^{\circ} \mathrm{C}$. DMSO $(200 \mu \mathrm{l})$ was added to dissolve the purple formazan. The quantity of formazan was determined by measuring the absorbance at a wavelength of $595 \mathrm{~nm}$ using a FilterMax F5 microplate reader (Molecular Devices, LLC, Sunnyvale, CA, USA). Cell viability was determined and compared with untreated MT-4 cells.
$H I V-1$ lytic effect. To determine the anti-HIV activity of APHCP on HIV-infected MT-4 cells, an MTT assay was performed. MT-4 cells were washed and resuspended in fresh RPMI-1640 medium, and seeded in duplicate in a 96-well plate at a density of $2 \times 10^{4}$ cells/well. A total of $24 \mathrm{~h}$ later, stock virus of HIV-1 $1_{\text {IIIB }}$ and HIV-2 $2_{\text {ROD }}$ were added to each well at $50 \mathrm{TCID}_{50}$ with different dilutions of APHCP. The plate was incubated for $84 \mathrm{~h}$ at $37^{\circ} \mathrm{C}$ with $5 \% \mathrm{CO}_{2}$. Cell viability was determined by an MTT assay as described previously (12).

p24 antigen assay. MT- 4 cells at a density of $2 \times 10^{4}$ were seeded in a 96-well plate. After 1 day, MT- 4 cells were treated with APHCP and infected with 50 TCID $_{50}$ of HIV $-1_{\text {IIIB }}$ and HIV-2 ${ }_{\text {ROD }}$. The plate was incubated for $84 \mathrm{~h}$. The supernatant was harvested by centrifugation at $200 \mathrm{x} g$ for $5 \mathrm{~min}$ at $4^{\circ} \mathrm{C}$. To determine the quantity of HIV, a Lenti-X ${ }^{\mathrm{TM}}$ p24 Rapid Titer kit (Clontech Laboratories, Inc., Mountainview, CA, USA) was used according to the manufacturer's protocol.

Reverse transcriptase (RT) activity assay. The activity of HIV-1 RT in the virus supernatant was determined using an RT assay kit (Roche Diagnostics GmbH, Mannheim, Germany) according to the manufacturer's protocol. Briefly, a reaction mixture containing poly(A)xoligo(dT $)_{15}$ was added to the virus supernatant and incubated for $4 \mathrm{~h}$ at $37^{\circ} \mathrm{C}$. Subsequently, anti-Digoxigenin-POD and 2,7'-azinobis[3-ethylbenzothiazolone-6-sulfonic acid] diammonium salt $(200 \mu \mathrm{l})$ were added stepwise. The virus supernatant was incubated at room temperature until the color development was sufficient for detection. The absorbance of the virus supernatant was measured at a wavelength of $405 \mathrm{~nm}$ using a microplate reader.

Syncytia formation analysis. The inhibitory effect of APHCH on syncytia formation was determined by visualization under a light microscope. MT-4 cells were seeded in a 96-well plate at a density of $2 \times 10^{4}$ cells/well. After $24 \mathrm{~h}$, the cells were infected with $10 \mu \mathrm{l}$ stock supernatant of HIV-1 $1_{\text {IIIB }}$ virus diluted at $50 \mathrm{TCID}_{50}$ in the absence or presence of APHCP. The plate was incubated for 3 days and the syncytia formation was observed by microscopy using an inverted light microscope [Zeiss LSM 510 confocal imaging system (Carl Zeiss, Oberkochen, Germany)].

Western blot analysis. MT-4 cells were seeded at a density of $2 \times 10^{4}$ cells/well in $80 \mu \mathrm{l}$ fresh medium and incubated for 1 day at $37^{\circ} \mathrm{C}$ with $5 \% \mathrm{CO}_{2}$. MT-4 cells were infected with HIV-1 $1_{\text {IIIB }}$ stock supernatant in the absence or presence of APHCP. After $84 \mathrm{~h}$, cells were pelleted at $200 \times \mathrm{g}$ for $5 \mathrm{~min}$ at $4^{\circ} \mathrm{C}$ and separated from the supernatant. MT- 4 cell pellets were harvested and solubilized in 2X SDS sample buffer containing $100 \mathrm{mM}$ dithiothreitol, $100 \mathrm{mM}$ Tris- $\mathrm{HCl}, 0.4 \%$ bromophenol blue, and $20 \%$ glycerol. The virus lysates $(25 \mu \mathrm{l})$ were loaded onto an $10 \%$ SDS-PAGE gel. Separated proteins were transferred to a polyvinylidene difluoride membrane (EMD Millipore, Billerica, MA, USA). The membranes were blocked for $1 \mathrm{~h}$ with $1 \%$ bovine serum albumin (Sigma-Aldrich; Merck Millipore) in $10 \mathrm{mM}$ Tris- $\mathrm{HCl}, 150 \mathrm{mM} \mathrm{NaCl}(\mathrm{pH} \mathrm{7.5)}$ containing $0.1 \%$ Tween-20, and incubated with primary antibodies against p24 (cat. no. MAB7360; R\&D Systems; dilution ratio 1:200) and $\beta$-actin (cat. no. MAB1501; Merck Millipore; dilution 


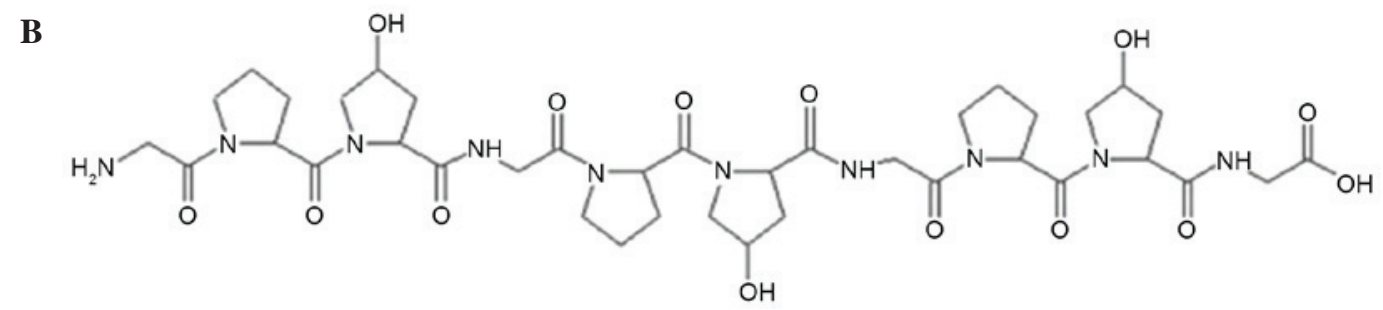

Figure 1.Peptide derived from the skin of Alaska pollack. (A) Amino acid sequence and (B) chemical structure of Alaska pollack skin hydroxyproline-containing collagen peptide.

ratio $1: 1,000)$ for $1 \mathrm{~h}$. The membranes were then washed and incubated for $30 \mathrm{~min}$ with the goat anti-mouse IgG secondary antibody conjugated to alkaline phosphatase (cat. no. sc-2008; Santa Cruz Biotechnology, Inc., Dallas, TX, USA; dilution ratio 1:1,000). The protein bands were detected by colorimetric reaction using 5-bromo-4-chloro-3'-indolyphosphate/nitro-blue tetrazolium alkaline phosphatase substrate (Sigma-Aldrich; Merck Millipore).

Statistical analysis. Data were analyzed using InStat statistics software (GraphPad 6.0 Software, Inc., La Jolla, CA, USA). Statistical comparisons were performed using one-way analysis of variance followed by Bonferroni post-hoc test for multiple comparisons. $\mathrm{P}<0.05$ was considered to indicate a statistically significant difference.

\section{Results}

A collagen peptide derived from Alaska pollack skin. A peptide derived from the skin of Alaska pollack was prepared and purified from protease E hydrolysates of Alaska pollack skin as described by Kim et al (11). The accurate molecular mass and amino acid sequence of the peptide as ascertained by Q-TOF mass spectroscopy and N-terminal Edman sequencing analysis was $787 \mathrm{Da}$ and Gly-Pro-Hyp-Gly-Pr o-Hyp-Gly-Pro-Hyp-Gly, respectively (Fig. 1). The amino acid sequence of this peptide was similar to that reported by Kim et al (11), except for having three or six additional amino acid residues [Gly-Pro-Hyp(-Gly-Pro-Hyp)] at the C-terminus. A database search of non-redundant protein sequences using the Basic Local Alignment Search Tool (blast.ncbi.nlm.nih.gov/Blast.cgi) revealed that the amino acid sequence of this peptide is the most typical sequence present in collagens. The present study named this peptide APHCP (Alaska pollack skin hydroxyproline-containing collagen peptide).

Cytotoxicity and anti-HIV-1 activity of APHCP. The cytotoxicity of APHCP in MT-4 human T cells was assessed. Cells were treated with $0-0.75 \mathrm{mg} / \mathrm{ml} \mathrm{APHCP}$ for $84 \mathrm{~h}$ and the viability of MT- 4 cells was measured by an MTT assay.
APHCP did not affect the viability of MT-4 cells at concentrations $<0.75 \mathrm{mg} / \mathrm{ml}$ (954 $\mu \mathrm{M}$; Fig. 2A).

The inhibitory effect of APHCP on HIV-1 infection in MT-4 cells was investigated. The protective effect of APHCP on HIV-1 ${ }_{\text {IIIB }}$-induced cell lysis was examined using an MTT assay. Cell lysis by $\mathrm{HIV}-1_{\text {IIIB }}$ infection was decreased following treatment with APHCP (Fig. 2B). The half-maximal effective concentration $\left(\mathrm{EC}_{50}\right)$ of APHCP against anti-HIV-1 ${ }_{\text {IIIB }}$ infection was assessed to be $0.403 \mathrm{mg} / \mathrm{ml}(459 \mu \mathrm{M})$. In addition, the effect of APHCP on HIV-1-induced syncytia formation was examined. Syncytia formation between HIV-infected cells and uninfected cells is a feature of HIV infection, and the fused cells are destroyed within a few days. Furthermore, the fusion of HIV-infected cells and uninfected cells is a critical step during the entry stage of HIV. APHCP-treated HIV-1 ${ }_{\text {IIIB }}$-infected MT- 4 cells behaved similarly to uninfected control cells, whereas HIV-1 $1_{\text {IIIB }}$-infected MT-4 cells fused with adjacent cells and formed syncytia. This suggested that APHCP inhibits HIV-1-induced syncytia formation by interfering with the fusion between HIV or HIV-infected cells and target cells (Fig. 2C). The inhibitory activity of APHCP on HIV-1 $1_{\text {IIIB }}$ infection was further studied by determining its effect on HIV-1 RT activity. The RT activity in infected host cells converts viral RNA to DNA, a critical stage of HIV-1 replication. APHCP treatment inhibited HIV-1 ${ }_{\text {IIIB }}$-induced RT activation in MT-4 cells in a dose-dependent manner (Fig. 2D). At a concentration of $0.5 \mathrm{mg} / \mathrm{ml} \mathrm{APHCP,} \mathrm{the} \mathrm{RT}$ activity in HIV-1 $1_{\text {IIIB }}$ infected cells was inhibited by $\sim 97 \%$ compared with the untreated control. The $\mathrm{EC}_{50}$ was assessed to be $0.327 \mathrm{mg} / \mathrm{ml}(374 \mu \mathrm{M})$. In addition, the anti-HIV-1 activity of APHCP was examined by quantifying p24 protein production. As p24 is a lentiviral capsid protein and is indispensable for subsequent reproduction of HIV in HIV-infected cells, it is an important indicator of viral replication in infected cells. As presented in Fig. 2E, p24 production was suppressed by $>90 \%$ in cells treated with $0.5 \mathrm{mg} / \mathrm{ml}$ APHCP compared with untreated cells. The $\mathrm{EC}_{50}$ of APHCP for HIV-1 ${ }_{\text {IIIB }}$-induced $\mathrm{p} 24$ production was calculated to be $0.356 \mathrm{mg} / \mathrm{ml}(405 \mu \mathrm{M})$. The inhibitory effect of APHCP on p24 production was confirmed by western blot analysis of cell lysates and culture supernatants using an anti-p24 antibody. APHCP treatment of cells 
A

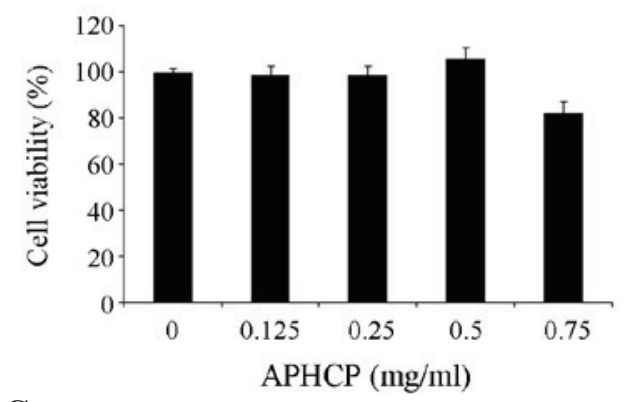

C

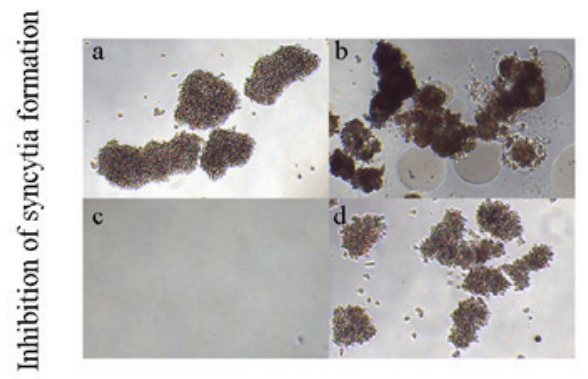

E

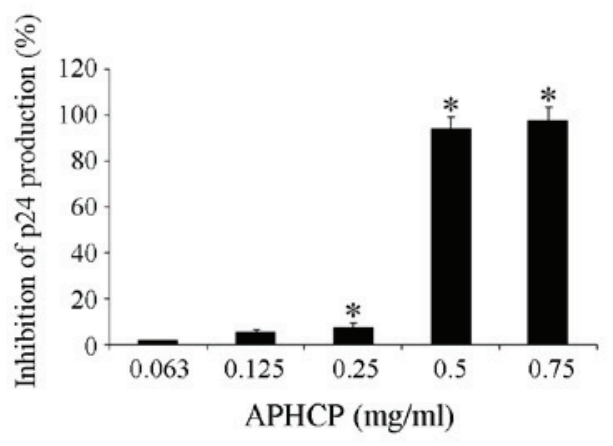

B

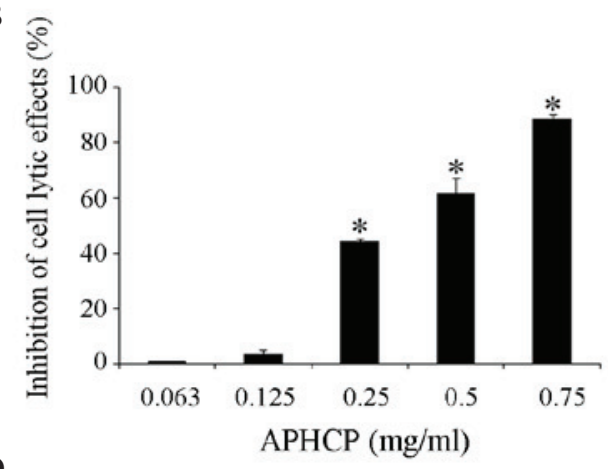

D

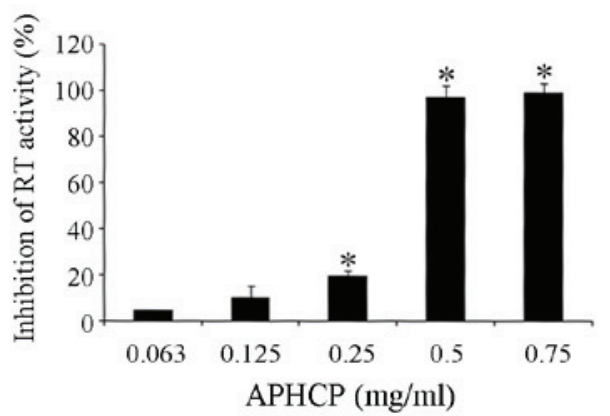

F

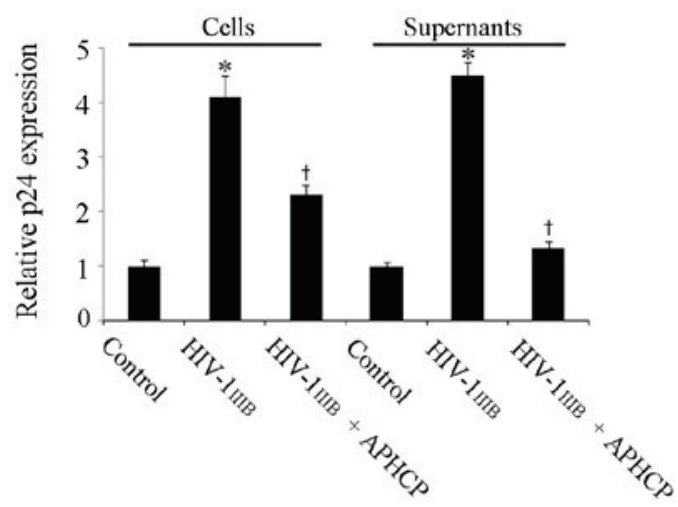

Figure 2. Cytotoxity and anti-HIV-1 activity of APHCP. (A) Effect of APHCP on the viability of MT-4 cells, as measured by an MTT assay. APHCP did not affect the viability of MT- 4 cells at concentrations less than $0.75 \mathrm{mg} / \mathrm{ml}$. Data are presented as the mean \pm standard deviation ( $\mathrm{n}=3$ ). (B) Effect of APHCP on HIV- $1_{\text {IIIB }}$-induced cell lysis, as measured by an MTT assay. Data are expressed as the percentage inhibition compared with HIV-1 $1_{\text {IIIB }}$-infected untreated control cells. Data are presented as the mean \pm standard deviation $(n=3)$. ${ }^{*} \mathrm{P}<0.05$ compared with HIV- $\mathrm{IIIB}_{\text {IInfected untreated cells. }}$ (C) Images of HIV-1 $\mathrm{IIIB}_{\text {-infected }}$ MT-4 cells. Syncytia formation was detected using an inverted light microscope (original magnification, x100). Representative images from 3 independent

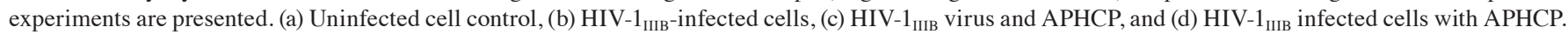
(d) has less syncytia formation than in (b) or was similar to the uninfected in (a). (D) Effect of APHCP on RT activity. Data are expressed as the percentage inhibition compared with $\mathrm{HIV}_{-} \mathrm{IIIB}_{\mathrm{II}}$-infected untreated control cells. Data are presented as the mean \pm standard deviation $(\mathrm{n}=3)$. " $\mathrm{P}<0.05$ compared with HIV-1 ${ }_{\text {ІІв }}$-infected untreated cells. (E) Effect of APHCP on p24 production by HIV-1 $1_{\text {ІІв }}$-infected MT- 4 cells. Data are expressed as the percentage inhibition

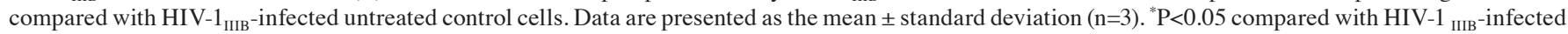
untreated cells. (F) Intracellular and secreted p24 protein expression levels were detected by western blot analysis. Data are presented as the mean \pm standard deviation ( $\mathrm{n}=3$ ). ${ }^{*} \mathrm{P}<0.05$ compared with $\mathrm{HIV}-1_{\text {IIIB }}$-infected untreated control cells. ${ }^{\dagger} \mathrm{P}<0.05$ compared with HIV- $1_{\text {IIIB }}$. APCHP treatment inhibited the lytic effects, syncytia formation, RT activity and p24 production of HIV-1 ${ }_{\text {шив }}$ infected MT-4 cells, in a dose-dependent manner. HIV, human immunodeficiency virus; APHCP, Alaska pollack skin hydroxyproline-containing collagen peptide; RT, reverse transcriptase.

decreased the HIV-1-induced p24 protein expression levels markedly in cells and supernatant (Fig. 2F). This inhibitory effect of APHCP on $\mathrm{p} 24$ protein production was similar to the results of $\mathrm{HIV}-1_{\mathrm{IIIB}}$-induced RT activity assay, indicating that the inhibition of HIV RT activity correlates well with that of subsequent HIV-1 replication activity. These results indicated that APHCP inhibits HIV-1-induced cytopathic effects by suppressing the fusion between HIV-infected and target cells, as well as HIV-1 RT activity and p24 production.

Specificity of APHCP for anti-HIV-1 activity. The specificity of the inhibitory effect of APHCP on HIV-1 infection was examined. As presented in Fig. 3A, APHCP did not inhibit HIV- $2_{\text {ROD }}$-infected MT-4 cell lysis. This result suggested 
A

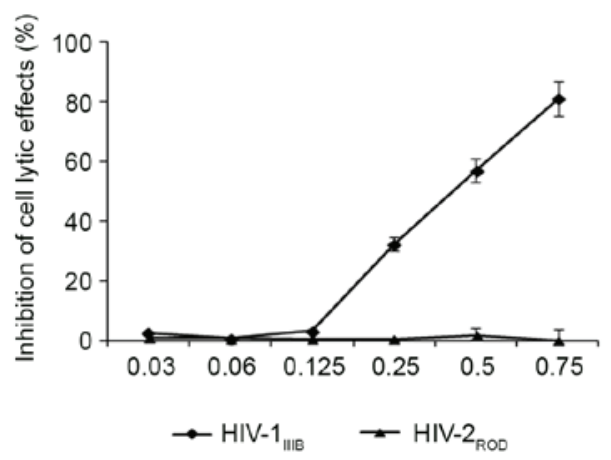

B

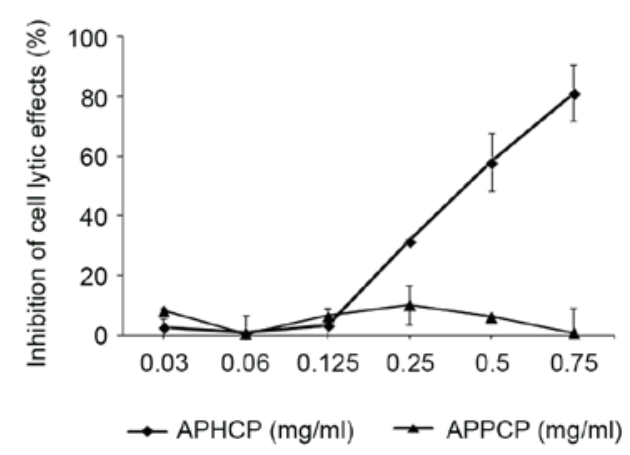

Figure 3. Specificity and essential residues of APHCP. (A) MT-4 cells were infected with HIV-1 ${ }_{\text {IIIB }}$ or HIV-2 ${ }_{\text {ROD }}$ in the presence or absence of APHCP. The cell lytic effect was measured by an MTT assay. APHCP did not inhibit the lysis of HIV-2 ROD -infected cells. Data are expressed as the percentage inhibition compared with HIV-infected untreated control cells. Data are presented as the mean \pm standard deviation (n=3). (B) To determine the essential residues responsible for the anti-HIV-1 activity, APPCP was synthesized in which the hydroxyproline residues in APHCP were replaced with prolines. MT-4 cells were infected with HIV-1 $1_{\text {III }}$ in the presence or absence of APHCP or APPCP. The cell lytic effect was measured by an MTT assay. APPCP did not inhibit the lysis of HIV-1 ${ }_{\text {IIIB }}$-infected cells. Data are expressed as the percentage inhibition compared with HIV-1-infected untreated control cells. Data are presented as the mean \pm standard deviation $(n=3)$. HIV, human immunodeficiency virus; APHCP, Alaska pollack skin hydroxyproline-containing collagen peptide; APPCP, Alaska pollack skin proline-containing collagen peptide.

that the anti-HIV activity of APHCP is specific to HIV-1. To examine the essential residues responsible for the anti-HIV-1 activity of APHCP, an Alaska pollack skin proline-containing collagen peptide (APPCP) was synthesized in which the hydroxyproline residues in APHCP were replaced by prolines. APHCP is composed of ten amino acid residues: Gly-Pro-HypGly-Pro-Hyp-Gly-Pro-Hyp-Gly. Various studies have reported that the tripeptide (Gly-Pro-Hyp) ${ }_{n}$ repeat is the primary component of collagen degradation products and that it adopts a triple-helical structure (13-16). The hydroxyproline residues in the peptide contribute to the stability and biological activity of the collagen triple helix (13-16). The anti-HIV-1 activity of APPCP was examined by measuring HIV-1 ${ }_{\text {IIIB }}$-induced lytic effects. APPCP did not demonstrate anti-HIV-1 activity (Fig. 3B), indicating that that hydroxyl group of hydroxyprolines is required for the anti-HIV-1 activity of APHCP.

\section{Discussion}

Currently, no cure or preventive vaccine is available for HIV/AIDS. A primary anti-HIV therapy combines the use of at least three antiretroviral drugs to achieve maximum suppression of the HIV virus and prevent the progression of HIV. Combination antiretroviral therapy has improved treatment; however, this treatment is lifelong, has serious adverse effects and causes viral resistance. Therefore, the identification of novel antiretroviral drugs with unique underlying mechanisms of action is required. In the present study, the marine peptide APHCP was assessed for its potential to provide effective treatment and prevention of HIV.

HIV infection has been demonstrated to cause collagen deposition (17-19). The virus induces an imbalance between matrix metalloproteinases (MMPs) and endogenous tissue inhibitors of MMPs, leading to remodeling of the extracellular matrix and HIV-associated pathology (20). The collagen triple peptide of Gly-Pro-Hyp may interfere with the binding of proMMP2 to fibrillar collagen, promoting the release and reducing activation of collagen-sequestered proMMP-2, which is associated with the resolution of liver fibrosis via fibrotic matrix-sequestered gelatinases $(21,22)$. Therefore, HIV infection-induced activation of collagen-sequestered proMMP2 may result in accelerated collagen resolution, tissue damage and the collapse of immune system. Hydroxyproline-containing triple collagen peptides, including APHCP, may prevent binding of proMMP2 to native collagen and promote the release of proMMP2 bound to fibrillar collagen, resulting in reduced MMP2 activation, collagen stabilization and immune cell homeostasis consistent with anti-HIV activity. Therefore, the structural and functional role of the collagen triple peptide may be important for the anti-HIV activity of APHCP in MT-4 cells. Further studies on the effect of APHCP on collagen remodeling are required to fully elucidate the underlying mechanisms of the anti-HIV activity of APHCP. This may provide a basis for further investigation into the use of the marine peptide APHCP as a potential therapeutic agent for the treatment of HIV/AIDS.

In conclusion, the results of the present study revealed that APHCP is non-cytotoxic at concentrations that inhibit HIV-1-induced cell lysis, syncytia formation, RT activity and viral p24 antigen production. APHCP is a novel, natural peptide with potent HIV-1 inhibitory activity and may be a potential therapeutic agent for the treatment of HIV-1.

\section{Acknowledgements}

The present study was supported by the Basic Science Research Program through the National Research Foundation of Korea, funded by the Ministry of Education, Science and Technology (grant nos. 2014-047149 and 2015-018506).

\section{References}

1. Gallo RC, Sarin PS, Gelmann EP, Robert-Guroff M, Richardson E, Kalyanaraman VS, Mann D, Sidhu GD, Stahl RE, Zolla-Pazner S, et al: Isolation of human T-cell leukemia virus in acquired immune deficiency syndrome (AIDS). Science 220: 865-867, 1983 
2. Barré-Sinoussi F, Chermann JC, Rey F, Nugeyre MT, Chamaret S, Gruest J, Dauguet C, Axler-Blin C, Vézinet-Brun F, Rouzioux C, et al: Isolation of a T-lymphotropic retrovirus from a patient at risk for acquired immune deficiency syndrome (AIDS). Science 220: 868-871, 1983.

3. Aldrich R and Wotherspoon G: Who's Who in Gay and Lesbian History: From Antiquity to the Mid-Twentieth Century Routledge, p528, 2001

4. Clavel F, Mansinho K, Chamaret S, Guetard D, Favier V, Nina J, Santos-Ferreira MO, Champalimaud JL and Montaqnier L: Human immunodeficiency virus type 2 infection associated with AIDS in West Africa. N Engl J Med 316: 1180-1185, 1987.

5. Kasedde S, Kapogiannis BG, McClure C and Luo C: Executive summary: Opportunities for action and impact to address HIV and AIDS in adolescents. J Acquir Immune Defic Syndr 66 (Suppl 2): S139-S143, 2014

6. Lee TG and Maruyama S: Isolation of HIV-1 protease-inhibiting peptides from thermolysin hydrolysate of oyster proteins. Biochem Biophys Res Commun 253: 604-608, 1998.

7. Plaza A, Bifulco G, Keffer JL, Lloyd JR, Baker HL and Bewley CA: Celebesides A-C and theopapuamides B-D, depsipeptides from an Indonesian sponge that inhibit HIV-1 entry. J Org Chem 74: 504-512, 2009.

8. Plaza A, Gustchina E, Baker HL, Kelly M and Bewley CA: Mirabamides A-D, depsipeptides from the sponge Siliquariaspongia mirabilis that inhibit HIV-1 fusion. J Nat Prod 70: 1753-1760, 2007.

9. Zampella A, Sepe V, Luciano P, Bellotta F, Monti MC, D'Auria MV, Jepsen T, Petek S, Adeline MT, Laprévôte O, et al Homophymine A, an anti-HIV cyclodepsipeptide from the sponge Homophymia sp. J Org Chem 73: 5319-5327, 2008.

10. Oku N, Gustafson KR, Cartner LK, Wilson JA, Shigematsu N, Hess S, Pannell LK, Boyd MR and McMahon JB: Neamphamide A, a new HIV-inhibitory depsipeptide from the Papua New Guinea marine sponge Neamphius huxleyi. J Nat Prod 67: 1407-1411, 2004.

11. Kim SK, Kim YT, Byun HG, Nam KS, Joo DS and Shahidi F: Isolation and characterization of antioxidative peptides from gelatin hydrolysate of Alaska pollack skin. J Agric Food Chem 49: 1984-1989, 2001.

12. Artan M, Li Y, Karadeniz F, Lee SH, Kim MM and Kim SK: Anti-HIV-1 activity of phloroglucinol derivative, 6,6'-bieckol, from Ecklonia cava. Bioorg Med Chem 16: 7921-7926, 2008.
13. Doig AJ: Statistical thermodynamics of the collagen triple-helix/coil transition. Free energies for amino acid substitutions within the triple-helix. J Phys Chem B 112: 15029-15033, 2008.

14. Dai N, Wang XJ and Etzkorn FA: The effect of a trans-locked Gly-Pro alkene isostere on collagen triple helix stability. J Am Chem Soc 130: 5396-5397, 2008.

15. Raman SS, Vijayaraj R, Parthasarathi R and Subramanian V: Helix forming tendency of valine substituted poly-alanine: A molecular dynamics investigation. J Phys Chem B 112: 9100-9104, 2008.

16. Squeglia F, Bachert B, De Simone A, Lukomski S and Berisio R: The crystal structure of the streptococcal collagen-like protein 2 globular domain from invasive M3-type group A Streptococcus shows significant similarity to immunomodulatory HIV protein gp41. J Biol Chem 289: 5122-5133, 2014.

17. Estes JD, Haase AT and Schacker TW: The role of collagen deposition in depleting $\mathrm{CD}^{+} \mathrm{T}$ cells and limiting reconstitution in HIV-1 and SIV infections through damage to the secondary lymphoid organ niche. Semin Immunol 20: 181-186, 2008

18. Diaz A, Alós L, León A, Mozos A, Caballero M, Martinez A, Plana M, Gallart T, Gil C, Leal M, et al: Factors associated with collagen deposition in lymphoid tissue in long-term treated HIV-infected patients. AIDS 24: 2029-2039, 2010.

19. Kusko RL, Banerjee C, Long KK, Darcy A, Otis J, Sebastiani P, Melov S, Tarnopolsky M, Bhasin S and Montano M: Premature expression of a muscle fibrosis axis in chronic HIV infection. Skelet Muscle 2: 10, 2012.

20. Mastroianni CM and Liuzzi GM: Matrix metalloproteinase dysregulation in HIV infection: Implications for therapeutic strategies. Trends Mol Med 13: 449-459, 2007.

21. Ruehl M, Muche M, Freise C, Erben U, Neumann U, Schuppan D, Popov Y, Dieterich W, Zeitz M, Farndale RW and Somasundaram R: Hydroxyproline-containing collagen analogs trigger the release and activation of collagen-sequestered proMMP-2 by competition with prodomain-derived peptide P33-42. Fibrogenesis Tissue Repair 4: 1, 2011.

22. Freise C, Ruehl M, Erben U, Farndale RW, Somasundaram R and Heimesaat MM: The synthetic hydroxyproline-containing collagen analogue (Gly-Pro-Hyp)10 promotes enzymatic activity of matrixmetalloproteinase-2 in vitro. Eur J Microbiol Immunol (Bp) 2: 186-191, 2012. 